Euskal ikerketen aldizkaria | Revue d'études basques |

Revista de estudios vascos | Basque studies review

$7 \mid 2002$

Numéro VII

\title{
Jeanne D'Arc Pastoralaren Eskuizkribua : Le plus ancien connu?
}

\section{Koro Segurola}

\section{OpenEdition \\ Journals}

Édition électronique

URL : http://journals.openedition.org/lapurdum/1032

DOI : 10.4000/lapurdum.1032

ISSN : 1965-0655

\section{Éditeur}

IKER

\section{Édition imprimée}

Date de publication : 1 octobre 2002

Pagination : 313-326

ISBN : 2-86781-321-2

ISSN : $1273-3830$

Référence électronique

Koro Segurola, « Jeanne D'Arc Pastoralaren Eskuizkribua : Le plus ancien connu ? », Lapurdum [Linean], 7 | 2002, Sarean emana----an 01 juin 2009, kontsultatu 01 mai 2019. URL : http://

journals.openedition.org/lapurdum/1032 ; DOI : 10.4000/lapurdum.1032 


\title{
Jeanne D'Arc Pastoralaren Eskuizkribua : Le plus ancien connu?
}

\author{
Koro SEGUROLA
}

Euskaltzaindia. EHHA

Zuberoako pastoralaren tradizioaz hitz egiterakoan eztabaida franko piztu duen gaia noizkoa den zehazterakoan izan da. Ez gara gu zuzen-zuzenean auzi honetan sartuko, alde batetik, ez delako idazlan honen helburua eta, bestetik, galdera hori ihardesteko lehenik herri-teatro tragiko honen lekukotasuna dakarten lehen dokumentuak noizkoak diren zehatz jakiteari beharrezkoa dela deritzogulako.

Dokumentu hauen artean aurkitzen da Jeanne d'Arc pastorala. Pastoral honen eskuizkribuari pleguak falta zaizkio, izenpetu eta datatu gabe aurkitzen $\mathrm{da}$, hau da, errejenta-kopistaren eskutik ez dakigu noiz eta non egina ${ }^{1}$ izan zen, eskuizkribuetan agertzen den datak pastorala noiz antzeztua izan zen, eta ez noiz idatzia, adierazten baitu.

Gaur egun esku artean ditugun dokumentu datatuen arabera edo zalantzarik uzten ez duten eskuizkribuetan fidatuz gero, pastoralen lekukotasun zuzen zaharrena $1750 \mathrm{ekoa}$ da, Sainte Elisabeth de Portugal deitua. Honek esan nahi du eskuizkribu horien artean agertzen den errepresentazio datarik zaharrena hori dela, 1750, hain zuzen ere. Lehenagokotzat emanak, halere, Jeanne d'Arc pastoralaz gain, beste hiru aipatzen dira literaturan : 1500 urtekoa omen zen Clovis pastorala, 1565 ingurukoa omen zen Artzain gorria deiturikoa (bi hauek galduak dira) eta azken urteetan eztabaida gehienik sortu duen Saint Jacques pastorala. Izan ere, zenbaitek egiten duten irakurketaren arabera (Hérelle, Urkizu) eskuizkribu honek $1634 \mathrm{ko}$ data darama ; haatik, eskuizkribuko urtearen idazketa artoski ikertu duen Beñat Oihartzabalek 1834 dela, zalantzarik gabe, ex-librisean idatzia dena ondorioztatzen du, aurreko irakurketa baztertuz. (Oihartzabal $1999: 81-85$ ).

Gaia. Jeanne d'Arc pastoralaz jadanik bi data adierazi dira : 1712 eta 1723. Datu hauen arabera eta B. Oihartzabalek Saint Jacques pastoralaz egindako ikerketan oinarrituz, oraindik eskuzta daitezkeen eskuizkribuen artean (datatuak diren ala ez kontuan hartu gabe) zaharrena Jeanne d'Arc genuke, hau da, Sainte Elisabeth de Portugal baino lehenagokoa. Horrela adierazita dago eskuizkribu hau 1712 urtean kokatu zuenaren eskutik ere : Le plus ancien connu. Esan behar da, halere, datu horren (1712) inguruko berri handirik ez dugula, nork esan zuen eta data adierazterakoan non edo zertan oinarritu zen ere ziur ez baitakigu. Haatik, 1723 urtean kokatzen zuen ikertzailea ezagutzen dugu eta azterbidearen berri ere eman digu, paperaren filigranan edo ur markan

1 Pastoral baten egiteaz honela diosku Beñat Oihartzabalek (1999:78) : Pastoral baten egitea tradizioan ez da pastoral baten idaztea baizik ere errepresentatzea edo antzeztea. 
oinarritutako emaitza dela adierazi baitigu ; alabaina, ez du paperean aurkitu zuen ur marka bera erakutsi, bertan, agidanean, ageri den data soila baizik.

Helburua. Datuak kontrajarriak eta herrenak direnez zalantzaz hartzekoak dira, gure ustez behintzat, eta hurbil-hurbiletik berriz aztertzea eskatzen dute. Asmo honetan, eskuizkribu hau 1712an, 1723an edo noiz idatzia izan zen ziur jakin ahal izateko paperaren azterketak duen garrantzia agerian utzi nahi genuke.

Azterbidea. Gure susmoak eta zalantzak argitzeko ere Jeanne d'Arc pastorala idazteko erabili zen papera aztertuko dugu, lehen mailako baliabide kronologikoa den paperaren ur marka, alegia, honen baliagarritasunaz ondo asko ohartu eta behin baino gehiagotan erabili baitugu gure ikerketa lanetan dokumentuak datatzeko orduan. Ez da dudarik testuaren barruko ezaugarriek horretan laguntzen dutela baina paperaren ezaugarririk garrantzitsuena den ur marka ere ahantzi gabe, baliabide ezin hobea baitugu paper horretan idatzitako testua noizkoa den jakitera iristeko. XII. mendearen amaieran eta XIII.aren hasieran papera identifikatzeko papergileak beren moldeetan jatorria adierazten zuten marrazki edo seinale batzuk jartzen hasi ziren. Honi ur marka deritzo, papera egiterakoan paperaren gorputz barnean ezarri zen bereizgarriari edo zeinuari, alegia (marca de agua, filigrane edo watermark izenez ere ezagutzen dena). Paperaren gorputz barnean ezartzen den zeinu edo irudi hau argiaren kontra baizik ezin daiteke ikus, itsatsitako ur marka papera bera baino gardenagoa bai baita. Marka honek lagunduko digu, hain zuzen ere, beste ezaugarriek baino zehatzago, paper hartan idatzitako testua noizkoa den jakiten. Ur marka motak eta erabiliak izan ziren urteak ongi ezagutzea lortzen bada, ez da dudarik aparteko laguntza izan daitekeela ikertzailearentzat. Izan ere, ur markaren bidez papera egin zen urtea jakin ahal izango da eta, hortaz, gutxi gora-behera bertan idatzia izan zenarena. Metodologia honetan oinarrituko gara, bada, ez beste ezertan, pastoral honen garaia finkatzeko.

Emaitzak. Paperaren ur markak bildu eta aztertu ondoren, Jeanne d'Arc pastorala noiz idatzi zen jakingo dugu, orain arte adierazi diren urteak baztertuz.

Ikus ditzagun lehenik orain arte pastoral honetaz dakigunaren edo jaso denaren berri zehatzagoak.

\section{Zer esan den Jeanne d'Arc pastoralaz}

Eskuizkribu hau Baionako Euskal Erakustokian aurkitzen da (25 zb.). Eskuizkribua gordetzen den karpetaren azalean, alde batetik, Manuscrit de 1712. Le plus ancien connu irakurtzen dugu. Irudiz hitz hauek Georges Lacombek idatziak dira baina ez da ziur. Bestetik, G. Hérellen hitzak (1928 134) jasotzen dira B. Oihartzabalen eskutik ${ }^{2}$ :

Cl. D'Andurain. Cahier sans couverture ; papier vergé, 250 sur 190 $\mathrm{mm}$. ; 40 feuillets à 2 colonnes. Incomplet de plusieurs feuillets arrachés ou pourris dans le corps et à la fin du cahier ; 1963 versets

\footnotetext{
${ }^{2}$ Hemendik eskerrak eman nahi dizkiot Beñat Oihartzabali eskuizkribu honen inguruko berriak eman eta eskaini didan laguntzagatik. Azterketa hau egiteko izan dudan aukera ere berari zor diot.
} 
comptés par le copiste, au dernier feuillet subsistant. Le papier porte dans le filigrane la date de 1723 , et l'écriture paraît être à peu près de la même époque.

Eskuizkribu hau, agidanean, D'Andurain de Maytie familian egon zen, Clément d'Andurain-en arrebak, Malartic Bizkondesak, utzi baitzuen 1935ean. Familia honen jatorria Maulen aurkitzen den D'Andurain de Maytie gazteluari lotua da. Gaztelu hau Oloroeko elizbarrutian egon ziren deitura bereko hiru gotzainetatik lehenak eraiki zuen XVII. mendean, Amaud de Maytiek, hain zuzen. Gogora dezagun, era berean, Zuberoa Oloroeko elizbarrutian zegoela Iraultza frantsesaren garaian ere. Lerro gutxi hauetan biltzen den historiaren lekuko eta erakusgai dugu Jeanne d'Arc, bere baitan, euskarrian bertan, islatzen baita ondoren erakutsiko dugun gisan. Orain arte, guk dakigunez, eskuizkribu honek nondik norako ibilbidea egin duen aipatu ez den arren jakingarri dela ezin uka, jatorria ezagutzen laguntzen baitu.

Pastoral honen aipamenak, bestenaz ere, urriak dira eta, gainera, era batera zein bestera datuak errepikatu egiten dira, urrunago joan gabe. Honela aurkezten du P. Urkizuk, esaterako, Historia del teatro vasco liburuan, Saint Jacques pastoralaren irakurketa 1634 dela ontzat eman ondoren :

Tras la pastoral de Saint Jacques, viene en orden cronológico la de Jeanne d'Arc (MS 25 del Museo Vasco de Bayona), que según nota de Georges Lacombe es de 1712, y le plus ancien connu, el más antiguo conocido. Se halla en un estado bastante deteriorado en papel que lleva la filigrana de 1723 , siendo la escritura aproximadamente de la misma época. Cuenta, a pesar de las numerosas hojas que le faltan con 1963 estrofas. [63 or.]

Eskuizkribu hau eskuetan izan edo honetaz hitz egin duten ikertzaileen artean iduri luke G. Hérelle izan dela paperean erreparatu eta, antza denez, ur marka ikusi duen bakarra. Ondorioz, baliabide honetan oinarrituz, eskuizkribua noizkoa den aditzera eman du, paperaren ur marka ezagutzen ez dugun arren 1723 urtea daramala baitio. Bestetik, eta irudiz G. Lacomberenak diren hitzetan irakurtzen ditugun datuak, 1712 eta le plus ancien connu, ez dakigu zein arrazoiz adierazitakoak diren. Are gehiago, eskuizkribua aztertu aurretik ere, Hérellek emandako datuan oinarritzen bagara, data hau, 1712, zalantzan ipintzekoa dela esan behar dugu ; izan ere, paperaren ur markak 1723 urtea badarama, ezinezkoa da idazkia $1712 \mathrm{koa}$ izatea, baliabide honen zehaztasunak ematerakoan eta ondoren egingo dugun azterketan ikusiko ditugun arrazoiengatik. Zernahi gisaz, kontuan hartzekoak dira gure emaitzekin alderatu ahal izateko.

Alde honetatik, ez gatoz gu gai honen inguruan piztu den eztabaida areagotzera, ezta gutxiagorik ere. Alta bada, datuaren iturburua adierazten ez denean eta, hala eginik ere, berau frogatzen ez bada, zalantzak eta susmoak sortzen dira ; zer esanik ere ez datuak bat ez datozela ikustean eta zehaztasun guztiak bildu gabe hala aurkezten direnean ere.

Hori guztia argitzeko, esan bezala, gu ere paperean oinarrituko gara, paperaren ur markak bildu eta aztertzen saiatuko gara. Aurretik, ordea, izkribuen datazioan paperaren ur markak duen garrantziaz jabetzeko, hitz 
gutxitan, paperaren beste ezaugarriak azalduko ditugu ondotik egingo dugun azterketaren emaitzak hobeto uler daitezen ${ }^{3}$.

\section{Azterbidea. Paperaren ezaugarriak : Formatua, Bilbea, Ur marka}

Paperaren kanpoko ezaugarriak bi motatakoak direla esan behar da : a) kalitateari dagozkionak eta b) molde edo formaren araberakoak. Azken hauek dira garrantzitsuenak. Formaren arabera paperaren ezaugarriak lautan banatzen dira : formatua, vergeure edo verjura deiturikoa, pontuseaux edo corondeles gisa ezagutzen dena eta, azkenik, filigrana edo ur marka. Papera datatzeko garaian ezaugarri hauetatik guztietatik ur marka dugu nagusiena. Izan ere, beste ezaugarriak kontuan hartzekoak diren arren, une jakin batean baliagarriak izan daitezkeelako, ez dira hain funtsezkoak aipatu helburua erdiesteko garaian orain ikusiko ditugun arrazoiengatik.

\section{Formatua}

Formatua edo orriaren tamaina papera egiteko erabili zen formaren araberakoa zen. Ez da ahaztu behar, ordea, lehortu eta kolatzerakoan paperak hartu egiten zuela, tamaina murriztuz. Beraz, molde berarekin eginiko paperak izan arren, luzeran bi edo hiru zentimetrotako aldea dituztenak aurkitzen dira.

Bestalde, neurriak aldatuz joan dira garaien eta beharren arabera. Sarritan, gainera, paperaren formatuak finkatzen eta batzen saiatu direnak agintariak izan dira, baina XIV. eta XVI. mendeetan (1398an eta 1540an) aurkitzen diren xedapenetan ez dira formatuen neurriak aipatzen. Ez gara orain datu zehatzetan sartuko, hau da, ez ditugu herrialde ezberdinetan erabili ziren formatu motak aipatuko (cf. 3) ; halere, paperaren neurriak finkatzen dituen xedapen frantses bat aurkitzeko, okerrik ezean, 1730 arte itxaron behar dela ohartarazi nahi genuke. Azkenik, Frantzia osorako prestatu zena 174leko irailaren 18an etorriko zen. Besteak beste, papergileek paperean jarri behar duten ur markaz aparte, urtarrilaren batetik aurrera urtea ipini behar dutela esaten da, 1742, hain zuzen ere. Kontuan hartzeko datua dugu hau, bai baitakigu paper ekoizpenean Frantzia zela lehena XVII. eta XVIII. mendeetan.

Aipatu dugun helburuari dagokionez formatua ez dela funtsezko ezaugarria esan daiteke. Izan ere, alde batetik, orrien neurriak aldatuz joan dira eta, bestetik, kontuan hartzen bada orriak ertzetatik moztu egiten zirela, neurrien aldaketek gutxi lagun dezakete paperaren data, nolabaiteko zehaztasunez, finkatzen.

\section{Bilbea 'Pontuseaux (corondeles) eta vergeure (puntizones)'}

Formaren azpia galbahe edo bahe baten antzekoa zen eta honen sarea osatzeko hari bertikalak (pontuseaux) eta horizontalak (vergeure) gurutzatzen ziren. Hari bertikalak motzagoak ziren eta bakanduago zeuden beren artean horizontalak baino. Hari horizontalak hurbilago zeuden elkarrengandik eta luzeagoak ziren. Denboraren buruan hari metalikoak ere erabili ziren.

\footnotetext{
3 Azalpen hauek zehatzago adierazten dira gure beste lan zabalago batean : "Paperaren ur markak". Oraindik argitaratzeko dagoenez, erreferentziarik gabe aurkezten dugu hemen atal hau, 'paperaren ezaugarriak'.
} 
Ore biguna galbahean edo moldearen azpian zegoenean, xukatzerakoan mugitzen zenez, geruzaren lodiera molde osoan berdina zen, hortaz, hariak zeuden aldeek ore gutxiago hartzen zuten eta orria leku hartan meheagoa zen. Horregatik papera zeharrargitara ikustean marra gurutzatu hauek nabari dira, gardenagoak orria bera baino.

Marra hauek bilbea edo trama osatzen dute eta ur marka bilbe honen gainean nabarmentzen da, orriaren erdian ezartzen delarik, eskuarki. Inoiz edo behin arrazoi ezberdinengatik, bilbearen marrak ur markaren irudiarekin nahas daitezke, gero, ur markak aztertzerakoan, ikusiko dugun gisan. Izan ditzakeen ondorioengatik kontu eta arreta handiz ibili behar da.

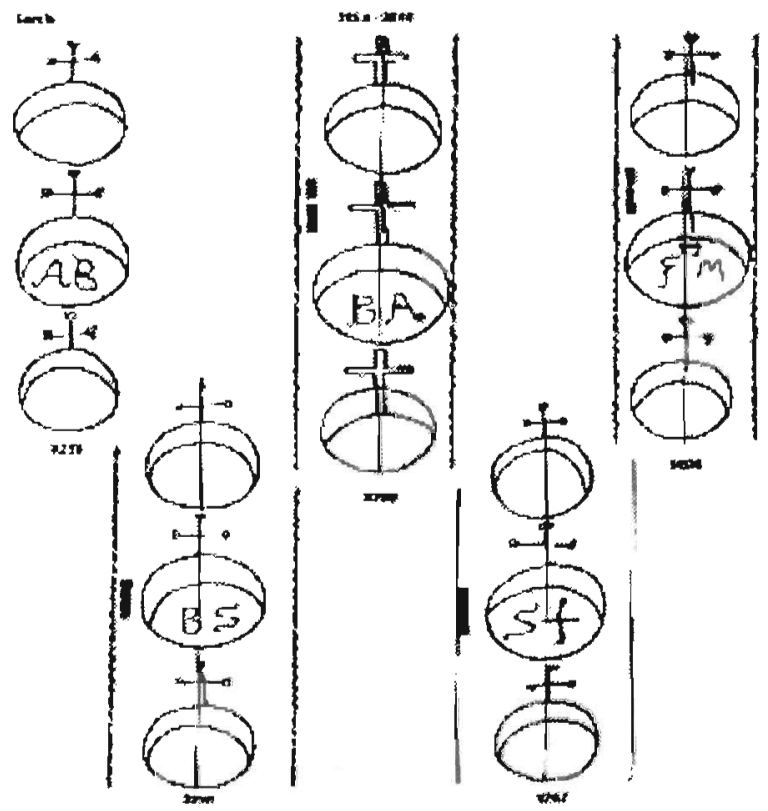

Zenbat hari jartzen ziren, ordea ? Kopurua eta beren arteko tartea oinarrizko elementuak ote dira paperaren data finkatzeko ? Denboran zehar kopurua eta tarteak aldatuz joan dira, baina ez da ikerketa sistematikorik egin honi buruz, ezta aldaketa horien arrazoirik adierazi ere.

Autore asko neurri batzuk ematera mugatu dira besterik gabe. Batzuetan, ordea, orrienak dira, besteetan, goitik behera doazen marren (pontuseaux direlakoen) arteko neurriak eta gutxien aipatzen direnak zentimetroko zeharkako marren kopuruarenak dira. Baina datu hauek guztiak ez dira lotu eta paperean agertzen diren datarekin erkatu. Beraz, oraindik umun dela dirudi papera datatzeko marra hauen arteko tarteak erabiltzeko aukera.

Nolanahi ere, kualitatiboki eta, oro har, papera berriagoa den heinean, marren arteko tarteak murriztu egiten direla ikusi da. Trama meheagoa egiten da eta hau aurrerapenaren edo hobekuntzaren adierazgarritzat hartu izan da. Horregatik esan ohi da paper ezberdinetan ur marka bera aurkitzen denean, goitik beherako marren tartea handiagoa duena izango dela zaharrena. Goitik beherako marren arteko tartea, ordea, orriaren neurriaren arabera aldatzen da. Tamainaz handiak diren orrietan tartea handiagoa dela ikusten da. Beraz, oharpen hori kontu handiz hartu behar da. Hori dela eta, papera datatzeko, tartearen berri jakitea ez dela garrantzia handikoa esan daiteke.

Horrezaz gain, tarte horiek aldatzearen eta garai berean hain ezaugarri ezberdinak dituzten paperak agertzearen azalpena bilatzea geratzen zaigu. Arrazoia paperak berak ematen digu.

Paper mota hauen kalitatea ezberdina da. Tarte handiak dituen papera gutxi landutako orez egina da. Askotan, kalitatea lehengaiari baino areago papergintzari berari lotua da. 
Garai berean ezaugarri ezberdinak dituzten paperak aurkitzeak errota zahar eta berriak aldi berean lanean ari direla esan nahi du, tresna edo lanabes ezberdinak erabiliz. Bitartekoek laguntzen ez dutela eta, paper-orea gutxi eta gaizki lantzen bada, lakainak luzeak eta lodiak dira eta, hortaz, baheak argi asko izan dezake. Orearen prestaketa hobetzen bada, berriz, lakainak landuagoak dira, motxagoak eta finagoak egiten dira eta honek formaren sare-mailaren argia ixtera behartzen du, paper-orria egiterakoan ore guztia goitik behera eta zeharkako hariz osatutako saretik pasa ez dadin.

Beraz, harien arteko tartea murriztea hobekuntza teknikoaren ondorio da. Hobekuntza hau ez zen aldi berean egin eta honek paper-errota zahar eta berriak batera aritu zirela lanean pentsarazten du.

Azalpen hauek gogoan harturik, paperaren ezaugarririk garrantzitsuena ur marka dela esan dezakegu.

\section{Ur marka}

Ur marken sorreraren eta erabileraren helburuaz luzaz eztabaidatu izan da. Hain goiz zabaldutako erabilerak bazuen, ordea, bere izateko arrazoia : ur markak baliagarriak ziren erabiltzen zituzten errotentzat, era berean, ezartzen zituzten aginteentzat eta eskatzen zituen erabiltzailearentzat ere.

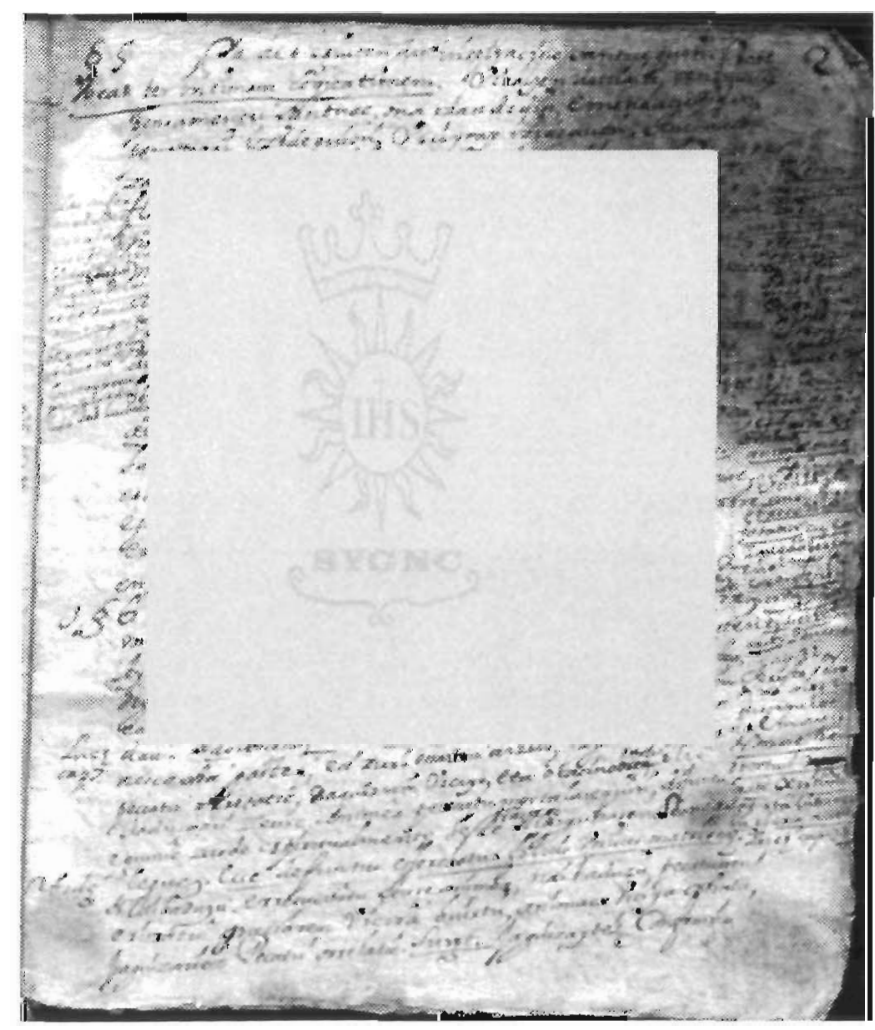

Esanahiaren aldetik onartu behar da papergileak berak izan zirela ur markak zeinu pertsonal edo lantegi-zeinu bezala sartu zituztenak, beren arteko 
ekoizpena bereizteko ${ }^{4}$. Marka pertsonala agertzeko funtzioaz gain, halere, ur markak jatorri baten adierazle gisa erabili ziren eta papergile bat ez ezik papererrota bat ere adierazten hasi ziren.

Paperaren kalitatea egilearen arretan ez eze, errotaren kokapenean ere bazegoen, eta erabiltzailearentzat ur markak papergilea baino areago paperaren jatorria adierazi behar zuen. Lurralde berean zenbait errota edo papertegi eraikitzen zirenean, ur markak eskualde horretako jatorria adierazteko erabiltzen ziren. Irudi nagusiaren ondoan (armarria, esaterako), eskuarki, bestelako zeinuak edo markak jartzen ziren (marka pertsonalak, inizialak...), eta hauek arreta berezia merezi dute, izan ere, horien bidez papergileak ezagut ditzakegu ${ }^{5}$.

Ur marka papera egin zen urtea adierazteko ere erabili izan da. Urtea daramaten ur markek erabilerari buruzko epeak egiaztatzeko aukera eskaintzen dute. Datatu gabeko idazkia ere bere garaian kokatzen laguntzen digute ur marka hauek. Ur markan ageri den data, ordea, papera egin zen garaikoa da, ez nahi eta nahi ez erabileraren unekoa.

Ur marka, bada, papergilea, jatorria, paperaren formatua edo kalitatea eta urtea adierazteko ere erabili dela esan daiteke, eta honek lagunduko digu, hain zuzen, beste ezaugarriek baino zehatzago, paper hartan idatzitako testua noizkoa den jakiten. Beraz, paperaren ur marka argitzea lortzen badugu Jeanne d'Arc pastorala noiz idatzi zen jakitera irits gaitezke.

\section{Jeanne d'Arc-en eskuizkribua : le plus ancien connu?}

Eskuizkribu hau gure eskuetan hartu genuenean egoera kaskarrean zegoela ohartarazi behar dugu, pleguak erdi askatuta eta orriek ere eskuetatik ihes egiten baitziguten. Zernahi gisaz, azaleko ezaugarri hauek nabarmenduko genituzke :

- Izenpetu eta datatu gabe aurkitzen da. Pleguak falta dira.

- Liburu gisa koadernatua. Azalik gabea. Testua lehen orrialdean hasten da.

- 41 orri ditu idatziak eta zenbatu gabeak. Hirugarren orria urratua dago baina hau ere kontuan izan dugu kopurua zehazterakoan. Ezin izan ditugu, bestalde, pleguak xuxen zenbatu, joskera bera ahula baita eta tartean orri batzuk ere aske baitaude.

- Papera XVIII. mendekoa da. Kalitate eskasa du. Kolore beltzezka.

- Neurriak : $260 \times 185 \mathrm{~mm}$.

- Esku batek baino gehiagok erabilia, tartean beste mota bateko letra eta tinta nabari baitira.

- Ia orri guztiek ur marka dute.

Hau guztia kontuan izanik, eskuizkribuaren muinean murgilduko gara. Pleguak banan-banan aztertu ditugu baina paperaren kalitatea eskasa dela-eta

\footnotetext{
${ }^{4}$ Briquet-en iritziz markarik zaharrenen (XIII. mendeetakoak) azterketak garbi frogatzen du hori eta ikerlari batzuek bestelako irizpideak azaldu badituzte, ur marken lehen garai hura ezagutu ez zutelako omen da (Les filigranes, 1923).

"Hauen argibiderako egindako zenbait azterketa eta zehaztasunak gure "Paperaren ur markak" izeneko lanean biltzen dira. Cf. 3 .
} 
zailtasun handiak izan ditugu, behin baino gehiagotan hartu behar izan ditugularik esku artean. Halere, arreta guztia ipinita, honako ur marka hauek aurkitu ahal izan ditugu :

- Irudia - $1793^{6}$. L PILLOT BEARN ${ }^{7}$

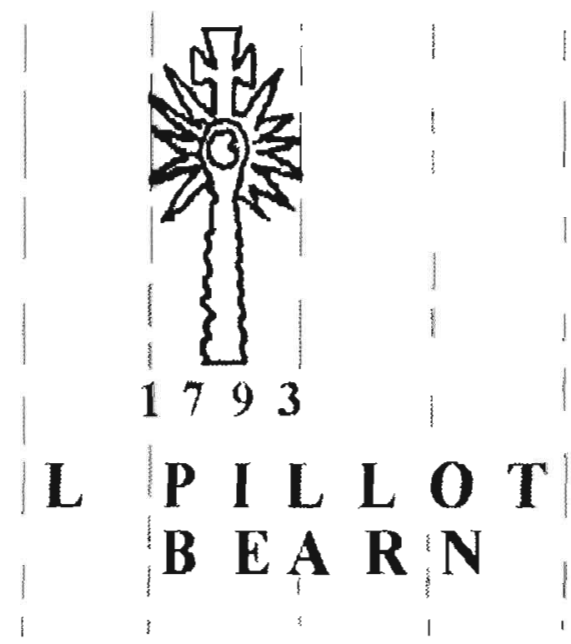

- Irudia $^{8}$. J BINOS F GURMENÇON ${ }^{9}$.

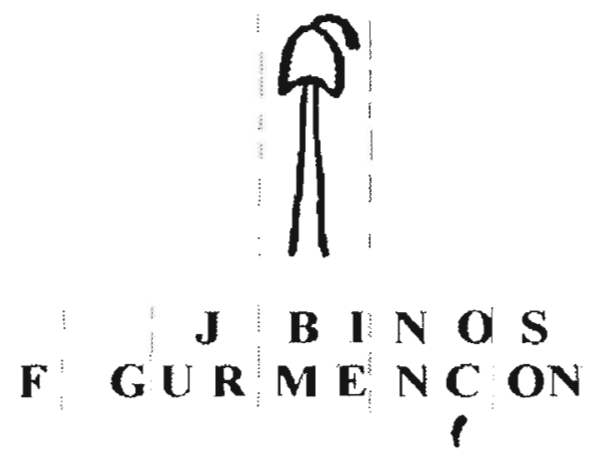

Ikus dezagun datu hauek zer adierazten diguten :

1. Jeanne d'Arc-en eskuizkribu hau ez zen 1793 baino lehenago idatzi

\footnotetext{
${ }^{6}$ Kontuan har pleguak tolestu eta ertzak moztu egiten zirela. Hori dela eta, paperaren urtea irudiarekin batera $6,8,10.14,15,16,18,20,22,23,30,31,34,36,37,40$ eta 41 . orrialdeetan aurkitu dugu. Bestetik, marra zuzenek bilbea osatzen duten hari bertikalak (pontuseaux) adierazten dituzte.

${ }_{7}^{7}$ Papergilearen izena eta paperaren jatorria $7,9,11,12,13,17,19,21,28,29,32,33,35,38$ eta 39. orrialdeetan ageri dira.

${ }^{8}$ Ondoko izenekin batera doan irudia, plegu berekoak baitira, 2 . orri askatuan eta 24. ean aurkitu dugu.

${ }_{9}^{9}$ Lau orri hauetan ikusten da : 3. orri urratuan, 25,26 eta 27 . orri askatuetan.
} 
Lehen ur markan ageri den datak papera 1793. urtean ekoitzi zela adierazten digu. Idazkia ezin da, bada, lehenagokoa izan, hau da, pastoral hau ezin izan zen idatzi 1712. urtean ezta 1723an ere handik hirurogeita hamar urtera ekoitzi zen paperean. Beraz, gutxienez, 1793an idatzi zen, inongo zalantzarik ez baitugu ur marka horretan irakurtzen den data 1793 dela.

Hérellek ur markan 1723 irakurri zuela eta, halere, azken froga bat egin nahi izan dugu bi datak, 1723 eta 1793, paperaren gainean ipinita. Honen ondotik, 9 zenbakiak bilbearen gainean nabarmentzen den irudia guztiz: estaltzen duela argi eta garbi ikusi dugun bitartean, 2 zenbakiak behean daraman arrasto etzana ez da bertan nabari. Nolanahi ere, 1793 urtea ageri den hamazazpi orrietan hiru era ezberdinetan irudikatua aurkitu dugu :

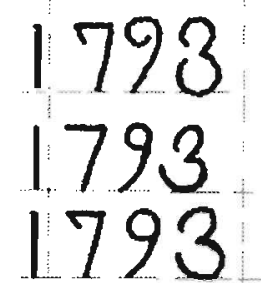

Zenbaki guztien amaiera edo behealdea, gainera, bilbea osatzen duten eta norabide luzeenean edo horizontalean diren marra horietako baten gainean dela ikus daiteke. Hori dela eta, 2 zenbakiak behean daraman arrasto etzana, agian, bilbearen marrarekin nahastu izana. Zailtasun handiagoak izan ditugu guk azken zenbakiarekin, goian ageri den lehen irudiko 3a lehen behakoan 8a zela iruditu baitzitzaigun. Ez da dudarik, ordea, hiruetan irakurtzen den urtea 1793 dela $^{10}$. Data hau, ordea, papera egin zenekoa da, ez nahi eta nahi ez erabileraren unekoa.

2. Bigarren ur marka Iraultza frantsesaren garaikoa da. Honek papera ez dela XVIII. mende hasierakoa adierazten digu, Iraultzaren (1789-1799) garaikoa baizik. Lehen ur markan data zehatza ematen denez, ez da dudarik idazkia 1793 koa dela, ez lehenagokoa.

3. Papera Biamon ekoitzia da, bigarren ur markan irakurtzen den Gurmençon ere Oloroe ondoko herri ttipia baitugu. Paperaren jatorria ikusita, kontuan izan behar da 1742an indarrean sartu zen araudia ; izan ere,

${ }^{10}$ Aldaera hauek ez dira arraroak, Briquet-ek eskaintzen duen ur markaren inudi bakoitzeko ere (tipo izendatzen du berak), gutxienez bi bai baitira ; batzuetan, lau edo gehiago, errotak ur marka hori erabili zuen denboran izan zituen tresken arabera, baina denak eirota berekoak ziren. Molde berean eginak direnei berdin-berdinak deitzen die, antzekoak berriz, elkarren artean ezberdintasun txikiak daudenean, eta ezberdintasun horiek oso nabarmenak direnean, dibergenteak. Sailkapen mota hau nahasgarri samarra da S. Real-en ustez. Irudiak alanbrez eta binaka egiten ziren, artisau baten lana izaten zelarik. Ur markak batera egin eta aldi berean erabiliko ziren moldeetan jarriagatik, ezin daitezke berdin-berdinak izan S. Real-en esanetan (1974 : 362). Molderik gabe, eskuz eginiko lanak aldaketa batzuk -txikiak izanik ere- ekar ditzake, are gehiago, hari metalikoa bezalako materialez lan egiten bada. Honenbestez, eta $\mathrm{S}$. Real-en iritziz, ur marka berdin-berdinak dituzten bi forma ezin dira egon. Orrietan halakoak ageri badira forma beretik eta bitarte laburrean ateratakoak direlako omen da. Erabileran, ur marka moldean lekualdatuz joaten zen eta ertzak ere desitxuratzen ziren. Forma pare batek, egoera onean, urtebete iraun zezakeela uste da. Hilabete batzuen barnan forma beretik ateratako orriak antzekoak izan daitezkeela onartzen du S. Real-ek (1974:363), esan bezala, lehenengoetatik azkenekoetara ezberdintasunak azaltzen direlako. 
honen arabera, papergileak forma berrietan data markatzera behartuta zeuden (cf. 3). Datu honek berak ere 1712 eta 1723 irakurketak baztertzen ditu, agindu horren aurretik data gutxitan agertu baitzen Frantzian egindako paperetan.

4. Ur markak urtea eta paperaren jatorria erakusteko ez ezik papergilea adierazteko ere erabili zirela agerian dugu, ondoan irakurtzen diren L Pillot eta J Binos deiturak bi ekoizlerenak baitira. Ditugun datuen arabera, hirurogeita hamarreko eta laurogeiko hamarkadetan Mirandetarrak dira Gurmençongo paper-errotako ekoizleak : 1774an G. Mirande eta 1781ean, berriz, P Mirande. Papergile hauek maisuak ziren lanbide honetan, Jean Brun, Jean Monié, Marc Raguette, Pierre Servat eta beste hainbaten artean.

5. Kalitatea dela eta, paper beltzezka eta, itxuraz, eskasa dela genioen. 1782an bildutako datuen arabera, gainera, Gurmençon-go paper-errota egoera txarrean zegoela adierazten da. Treska bakarra zuen eta guztia trakets antolatua. Ez zuen urte osoan lan egiten, sei hilabetez besterik ez. Paperak ez ziren garbiak, zuriak ; ilunak edo ke kolorekoak baizik. Ez da berdin esaten Mirepeix-en edo Sarrance-n egiten zen paperaz, onenetakoak baitziren. Honek guztiak garai berean ezaugarri ezberdinak dituzten paperak aurki daitezkeela erakusten digu, paperaren kalitatea egilearen arretari ez ezik errotaren kokapenari, lehengaiari eta, askotan, papergintzari berari ere lotua baita. ${ }^{11}$

6. Azkenik, papera garai honetakoa dela (XVIII. mende amaierakoa) egiaztatzen digun beste datu bat gaineratu nahi genuke : Gipuzkoako Getaria herrian 1796an Nicolas Gorostidi notarioaren hitzak jasotzen diren pleguan bigarren ur markan ageri den irudia aurkitu dugu, Iraultza frantsesaren garaikoa, hain zuzen ere.

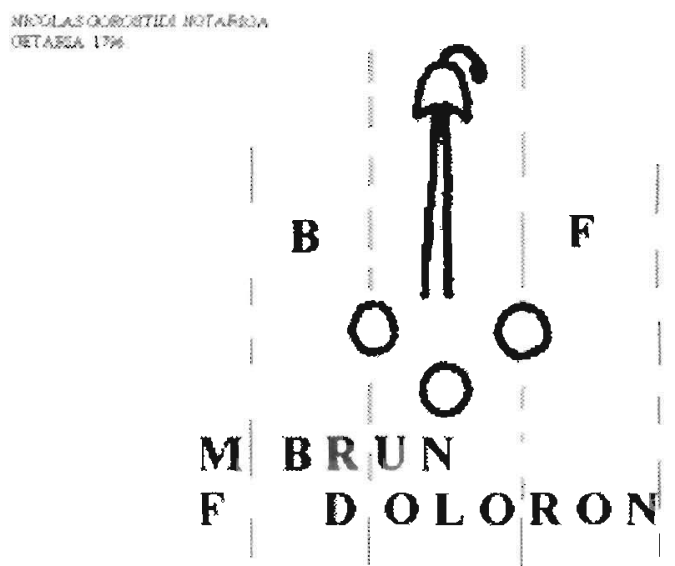

"Honenbestez, esan behar dugu garai honetan eta lehenago ere kalitate hobeagoko paperak izan ditugula esku artean. 
Ur marka honek jatorrizko dokumentu baten aurrean aurkitzen garela adierazten digu eta erabileraren epea egiaztatzen ${ }^{12}$. Paper hau ere Biarnokoa da, Oloroen ekoitzia, eta gogora dezagun, bestalde, lurralde berean zenbait errota edo papertegi eraikitzen zirenean ur markak eskualde horretako jatorria adierazteko ere erabiltzen zirela. Irudiaren azpian hiru biribil ageri dira eta irudiaren alde banatan letrak edo inizialak, baina hauek marka pertsonalak dira. Ekoizlea M( ?) Brun dela adierazten da. 178lean Brun familiak bazuen jadanik Mirepeix-en paper-errota, Jean Brun ageri baita. bertako ekoizlea. Hemen egiten zen papera, gainera, merkatari baten bidez Iruñera eramaten zen ${ }^{13}$.

Hau guztia paperak daraman ur markaren azterketak duen garrantziaren lekuko dugu. Orobat idazlan honek plegu guztiak arretaz begiratu eta aztertu behar direla ere agerian uzten du, ezustekorik gerta ez dadin.

\section{Azken hitzak}

Azterketa honen ondotik, zer esan ote daiteke ? Lehenik, izkribua datatu gabe egon arren ur markak aztertuta idazkiaren garaia edota urtea jakitera irits gaitezkeela, Jeanne d'Arc pastoralean erakutsi dugun gisan. Baionako Erakustokian den pastoralaren eskuizkribu hau, gutxienez, 1793. urtean idatzi zen, ez lehenago, papera urte honetan ekoitzi zelako eta, hori gutxi balitz bezala, Iraultza frantsesaren garaiko ur marka ere daramalako. Pastoralaren testua beranduagokoa ere izan daiteke, hau da, ez papera egin zen garai berekoa, data horrek ez baitu erabileraren unea adierazten. Oraingoz, ordea, ezin dugu gehiago zehaztu, testua oraindik argitaratu ez delako. Paperaren azterketa honetan oinarrituz, halere, idazkia ez dela 1793 baino lehenagokoa ziur esan dezakegu.

Hori dela eta, eskuizkribu honen azterketak ere ez garamatza hemezortzigarren mendeko mugatik haratago pastoralen historian. Hala eta guztiz ere, G. Hérellek egin zuen irakurketatik (1723) guk adierazi dugunera mende erdi bat baino gehiagoren aldea dugu. Are nabarmenagoa da eman zen beste datari (1712) erreparatzen badiogu.

Bestetik, eskuizkribu hau ezin dugu le plus ancien connu denik esan, Sainte Elisabeth de Portugal baino berrogeita hiru urte beranduago idatzia

Kontuz ibili behar da, halere, iruzurrak egon baitaitezke. Gertatu izan da notario batek aurkeztutako eskriturak atzera botatzea, bertan ematen zuen data ur marka baino lehenagokoa zelako.

13 Jeanne d'Arc-en eskuizkribuan ageri den lehenengo ur marka, bestalde, urtea daramana, alegia, ezezaguna egin zaigula esan behar dugu, gure ur marken bilduman ez baitugu aurkitu. Bilduma honetan Hegoaldeko zenbait agiritan aztertu ditugun eskuizkribuetan ageri diren ur markak bildu ditugu, batez ere, XVIII. mendekoak. Zernahi gisaz, Hegoaldean garai honetan, batik bat, Biarno, Bigorra, Perigord eta inguru horretan ekoitzitako papera aurkitu dugula argitu behar dugu. Bakarren batzuk Nafarroa Beherean eta Zuberoan eginak ere izan ditugula esku artean nabarmendu nahi genuke. Zubcroan ekoitzitako paperak, gainera, XVIII. mendearen erdira baino lehenagoko garaietara garamatza, 1744ra, hain zuzen ere. Honek Ipar Euskal Herrian Hegoaldean baino lehenago hasi zela papera ekoizten adierazten digu. Izan ere, Hego Euskal Herriko lehenengo paper-errota 1753-1754an ezagutzen da eta Iruñean kokatzen da, Iruñeko Ospitale Nagusiko bolbora-fabrika izandako batean eraikia. Lehenengo paper sortak 1755ean egiten dira eta paperak 'Hospital General de Pamplona' eta lehoia daramatza ur markatzat, ospitalea izan baitzen, hain zuzen, horren bultzatzailea edo sortzailea. Bizkaiko lehenengoa, Berrizkoa, 1779an hasi zen lanean. Gipuzkoakoa, berriz, 1803 an eraiki zen Alegia izeneko herrian eta paper-errota hau abiarazi zuena, gainera, Joannes Ibar zuberotarra izan zen. (Labayen 1967:4). 
baita. Guk eskuetan eduki dugu eskuizkribu hau, Sainte Elisabeth de Portugal, alegia, eta Oihartzabalek ere dioen gisan (1999:79), bertan irakurtzen den data duda-mudarik gabe 1750 dela ziurta dezakegu ${ }^{14}$. Halere, data hau egiaztatu nahi izan dugu paperaren ur markak aztertuz : 5 zenbakia ( 29 eta 61 orrietan) eta letra batzuk irakurtzea besterik ez dugu lortu, pleguak ez baitaude ertz-ertzetik josita barruagotik baizik eta ur marka osorik ikus ahal izateko guztiak askatu behar direlako. Honek baimen kontuak eta bestelakoak eskatzen dituenez, bere horretan utzi dugu, gure ikerketaren helburu zuzena Jeanne d'Arc-en eskuizkribua baitzen. Nolanahi ere, eta oraingo honetan gure zereginetik at gelditu den arren, idazkiak urtea daramanean ere hori egiaztatzea komeni dela azpimarratu nahi genuke, paperaren ur markak aukera hau ere eskaintzen digunez gero. Gertatu izan zaigu idazkian ematen zen data egiaztatzeko papera aztertu eta bat ez etortzea, hots, paperaren ur marka beranduagokoa izatea ${ }^{15}$. Horrelakoetan, hau da, idazkian ematen den data papera baino lehenagokoa denean, kopia baten aurrean egon gaitezkeela pentsatu behar da eta dituen ondorioengatik data ongi ziurtatzea eta egiaztatzea behar-beharrezkoa da, ur markak idazkiaren jatortasuna agerian uzten baitu.

Dena den, idazki motak kontuan hartu behar dira paperaren erabilera aztertzeko garaian. Kasuistika zabala da eta zuhurtziaz jokatzea komeni da. Ziurra dena da ur markak daraman data, datu zehatza eta objektiboa baita idazkia garaian kokatu behar denean. Norbaitek galdegin dezake, halere, "baina nola liteke Jeanne d'Arc pastorala Iraultza frantsesaren garaian idatzi izana ?" Erantzuna Iraultzak hartu zuen bidean edo izan zituen ondorioetan beretan egon daiteke.

Gogora dezagun, hitz gutxitan, 1793ko apirilean hasi zela Konbentziogerra. Ordurako, Lapurdi, Nafarroa Beherea eta Zuberoako foruak galdu eta Biarnorekin batera Pirinio Behereko departamentuan bilduak zituzten (1790). Departamentu honetako gotzaindegia Oloroen kokatu zuten. Garai honetan, 1790ean, apaizei konstituzio zibila ezarri zieten. 1791 an Asanblada legegileak konstituzioa onartu nahi izan ez zuten apaizen deportazioa agindu zuen. 1792an jakobinoek Austriari gerra deklaratu zioten, gobernua hartu eta Konbentzio Nazionala ezarri zuten, girondinoak konbentziotik baztertuta. Erregea preso hartu eta monarkiari amaiera eman zioten. Errepublika aldarrikatu eta Belgika hartu zuten. 1793an Luis XVI.a gillotinatu eta girondinoak atxilotu egin zituzten. Jakobinoek erregimen errepresiboa ezarri zuten, Izualdia izenaz ezaguna. Aldi honetan (1793-1794) Lapurdiko lau mila euskaldunetik gora deportatuak izan ziren. Sarako herria hutsik gelditu zen eta bertako bizilagunak Landetara eramanak izan ziren. 1794ko uztailean gobernua erori eta Robespierre hil egin zuten. Iraultzaren aurkako mugimendua hasi zen, herriá miseria gorrian baitzegoen.

Ez dugu gehiago luzatuko, baina Elizaren aurkako giro politikoan eta izua nagusi zen aldian idatzi zen Jeanne d'Arc. Alde honetatik, garai horretan pastoral hau idatzi izanak protesta edo erreakzio gisa egindako idazkia izan daitekeela pentsarazten digu.

${ }_{15}^{14}$ Baionako Euskal Erakustokian, MS. 63.14, $14 \mathrm{zb}$

${ }^{15}$ Ezusteko hau Oikiako Dotrina-ren azterketaren ondotik iritsi zitzaigun. Oraindik argitaratzeko dagoen "Oikiako Dotrinak. Francisco Antonio Aguirre (Marín 1728 - Oikia 1805)" izeneko lanean aurkitzen da gure azterketa hau. 
Hemezortzigarren mendearen amaierakoa da pastoralen lehenengo debeku aipatua ere, $1796 \mathrm{koa}^{16}$, hain zuzen, hauek nahasmendutzat hartzen baitziren : la simple représentation d'une pastorale où nécessairement interviennent rois et saints constitue une preuve d'hostilité au régime, et les rassemblements qu'elle entraine en cela la Révolution reprend l'héritage ancien-sont considérés comme source d'immoralité et de désordres. [Hérelle 1910, Oyharçabal 1991].

Garai horretan, eta erlijioaren kontrako politikari erantzun nahian, kantek ere izan zuten garrantzia azpimarratzen du Christian Desplat-ek ${ }^{17}$ : Entre las formas originales de la resistencia vasca a la descristianización hay que subrayar la importancia de la canción. En realidad, ésta formaba parte de las formas tradicionales de contestación política y de la sátira social bajo el 'Antiguo Régimen. No es, pues, nada extraño que fuera utilizada por los adversarios de la Revolución. Pero, precisamente, conocemos mury mal a los compositores de tales canciones, asi como la fecha en que fueron divulgadas entre la población. iSe trata de canciones muy posteriores a los acontecimientos, obra de gente de letras, sin duda eclesiásticos, que intentaban reprogramar la memoria popular y despertar su hostilidad contra la Revolución? ¿O por el contrario fueron compuestas en el momento mismo de los hechos, por autores populares? Nada nos permite responder con certeza a tales cuestiones en el estado actual de la investigación. Entre estas canciones, la "Complainte des fugitifs de Sare" parece haber sido obra de un clérigo. (...) Los exiliados acusan al cura constitucional, "toi cause de notre malheur, tu as dévoré la chair vivante de nos poitrines!" Invocan después la clemencia divina para poder volver a ver de nuevo un día Sara y su iglesia. (...) "La Révolution française" era una canción más ambiciosa, atribuida por la tradición a un eclesiástico emigrado que la habia compuesto tras la muerte de Luis XVI. (...) El autor de esta canción insistía sobre la incompatibilidad de la legislación revolucionaria con los preceptos evangélicos. (...). Pero era ante todo la política antirreligiosa de la Revolución lo que se condenaba con mayor fuerza: la incautación y venta de los bienes eclesiásticos, el nuevo calendario, "les décadis tirés du coeur de Satan" y, evidentemente a los curas constitucionales. [72-73].

Pastoral bat antzeztua izateko idatzia den arren, ez dakigu noiz eraman zen Jeanne d'Arc oholtza gainera, ezta debekuaren zigorra jaso eta zokoan geratu ote zen ere. Jakin badakigu, ordea, paperaren ur marka baliabidetzat hartuta, gutxienez XVIII. mende amaieran, Iraultza frantsesaren garaian, idatzi zela. Erranak erran, izan ere, ur markei esker ez zaigu dokumentuaren jatortasunaz zalantzarik gelditzen eta desadostasunak egongo balira azterketa honen ondokoak lirateke, ur marka beti egiaren fede-emaile izango baita.

\section{Bibliografia}

Jeanne d'Arc, Baionako Euskal Erakustokian, sinadua zb. 25.

Sainte Elisabeth de Portugal, Baionako Euskal Erakustokian, 63.14, 14 zb.

\footnotetext{
${ }^{16}$ Debekua hautsi egin zen, ordea, eta ondoren kantonamenduko agintariek agiri bat egin zuten. Testu hau argitaratua dago. Ikus Oyharçabal (199l: 25-26).

${ }_{17}$ Adrián Blázquez Carbajosa-k frantsesetik itzulia. Desplat, Ch., 1991, "El clero vasco-francés y la Revolución", Ilustración y Revolución Francesa en el Pais Vasco, 61-76.
} 
Bofarull y Sans, Francisco de, 1901, "La heráldica en las filigranas del papel", Memorias de la Real Academia de Buenas Letras, VII, 485-556, Barcelona. , 1910, Los animales en las marcas del papel, Villanueva y Geltrú, Oliva. Bouyer, Christian, 1994, L'histoire du papier, Belgique, Brepols.

Briquet, Charles-Moïse, 1923, Les filigranes. Dictionnaire historique des marques du papier dès leur apparition vers 1282 jusqu'en 1600, I-II-III-IV, Leipzig, Karl W. Hiersemann, (1968, 1977, 1985).

Buquet, Alain, 1991, L'expertise des écritures manuscrites, París, Masson.

Cabanes Pecourt, $M^{a}$ D., Cabanes Catalá, $M^{a}$ L., 1974, "Las filigranas del Archivo Municipal de Estella", Principe de Viana 35, n. 136-137, 483-505, Pamplona.

Garcia Serrano, Rafael, 1974, "El molino de papel del Hospital General de Pamplona", Cuadernos de Etnología y Etnografía de Navarra 16, 7-21.

Gayoso Carreira, Gonzalo, 1973, "Antigua nomenclatura papelera española", Investigación y técnica del papel 35. , 1994, Historia del Papel en España I-II-III, Lugo.

Hérelle, Georges, 1910, "Les représentations des pastorales basques dans la Soule pendant la période révolutionnaire", RIEV. , 1918, "Les problèmes relatifs aux pastorales", RIEV IX, 80-140. , 1926, Les pastorales à sujets tragiques considérées littérairement, Paris. , 1928, Répertoire du Théâtre tragique. Catalogue analytique, Bayonne.

Labayen, Antonio Maria, 1947, Escenas Papeleras, Zarauz, Icharopena.

, 1967, “Cuál fue la primera fábrica de papel en Guipúzcoa ?”, BRSVAP 23, 1, 101-104.

La Lande, Mr. de, 1778, 1995, Arte de hacer el papel según se practica en Francia y Holanda, en la China y en el Japón, Madrid, Clan.

Oyharçabal, Beñat, 1991, La pastorale souletine. Édition critique de Charlemagne, $A S J U$-ren gehigarriak XVI, Donostia.

Oihartzabal, Beñat, 1999, "Noizkoak diren Zuberoako pastoralei dagozkien lehen dokumentuak", Euskera XLIV, 1 (Separata), 69-88.

Panyella, L., 1976, La Filigrana de papel, Burriana, Papelera del Mijares, S.A., Papelera del Cid, S.A.

Sánchez Real, José, 1974, "Criterios a seguir en la recogida de filigranas", Ligarzas 6, 361-371.

Segurola, Koro, 2001, "Paperaren ur markak" (Argitaragabea).

Urkizu, Patri, 1996, Historia del teatro vasco.

Valls i Subirà, Oriol, 1970, El papel y sus filigranas en Cataluña / Papier and watermarks in Catalonia I-II, Amsterdam, Paper Publications Society (Labarre Foundation). 